Waste/Rock Interactions Technology

Program

\title{
Leach Test Methodology for the Waste/Rock Interactions Technology Program
}
D. J. Bradley
G. L. McVay
D. G. Coles

May 1980

Prepared for the

Office of Nuclear Waste Isolation

Under its Contract with the

U.S. Department of Energy

Pacific Northwest Laboratory

Operated for the U.S. Department of Energy

by Battelle Memorial Institute 


\title{
NOTICE
}

This report was prepared as an account of work sponsored by the United States Government. Neither the United States nor the Department of Energy, nor any of their employees, nor any of their contractors, subcontractors, or their employees, makes any warranty, express or implied, or assumes any legal liability or responsibility for the accuracy, completeness or usefulness of any information, apparatus, product or process disclosed, or represents that its use would not infringe privately owned rights.

The views, opinions and conclusions contained in this report are those of the contractor and do not necessarily represent those of the United States Government or the United States Department of Energy.

\author{
PACIFIC NORTHWEST LABORATORY \\ operated by \\ BATTELLE \\ for the \\ UNITED STATES DEPARTMENT OF ENERGY \\ Under Contract DE-AC06-76RLO 1830
}

\author{
Printed in the United States of America \\ Available from \\ National Technical Information Service \\ United States Department of Commerce \\ 5285 Port Royal Road \\ Springfield, Virginia 22151 \\ $\therefore$ Microfiche $\$ 3.00$
}

Price: Printed Copy $\mathbf{S}$

•Pages Selling Price

001-025

026-050

051-075

076-100

101-125

126-150

151-175

$176-200$

201-225

226-250

251-275

$276-300$

NTIS

$\$ 4.00$

$\$ 4.50$

$\$ 5.25$

$\$ 6.00$

$\$ 6.50$

$\$ 7.25$

$\$ 8.00$

$\$ 9.00$

$\$ 9.25$

$\$ 9.50$

$\$ 10.75$

$\$ 11.00$ 
33679000544645

Waste/Rock Interactions Technology Program

LEACH TEST METHODOLOGY FOR THE WASTE/ROCK INTERACTIONS TECHNOLOGY PROGRAM

D. J. Bradley

G. L. McVay $(a)$

May 1980

Prepared for

the Office of Nuclear Waste Isolation under its contract with the U.S. Department of Energy

Pacific Northwest Laboratory

Richland, Washington 99352

(a) Lawrence Livermore Laboratory 


\section{SUMMARY AND CONCLUSIONS}

Experimental leach studies in the WRIT Program have two primary functions. The first is to determine radionuclide release from waste forms in laboratory environments which attempt to simulate repository conditions. The second is to elucidate leach mechanisms which can ultimately be incorporated into nearfield transport models. The tests have been utilized to generate rates of removal of elements from various waste forms and to provide specimens for surface analysis. Correlation between constituents released to the solution and corresponding solid state profiles is invaluable in the development of a leach mechan ism.

Several tests methods are employed in our studies which simulate various proposed leach incident scenarios. Static tests include low temperature (below $100^{\circ} \mathrm{C}$ ) and high temperature (above $100^{\circ} \mathrm{C}$ ) hydrothermal tests. These tests reproduce nonflow or low-flow repository conditions and can be used to compare materials and leach solution effects. The dynamic tests include single-pass, continuous-flow (SPCF) and solution-change (IAEA)-type tests in which the leach solutions are changed at specific time intervals. These tests simulate repository conditions of higher flow rates and can also be used to compare materials and leach solution effects under dynamic conditions. The modified IAEA test is somewhat simpler to use than the one-pass flow and gives adequate results for comparative purposes.

Early in the WISAP program, a modified version of the IAEA test was adopted to obtain leach rate data. Since this test uses varying solution renewal times, the test has been questioned with respect to: 1) the possible effect of varying solution renewal times on the leach rate, and 2) the fact that this sampling scheme does not correctly model the anticipated waste/solution contact in a geologic repository. However, recent studies (Bradley, Harvey and Turcotte 1979; Weed and Jackson 1979) have shown that solution renewal at 10 temperatures $\left(25^{\circ} \mathrm{C}\right)$ does not have a significant effect on leach rates, and may be element dependent. These studies also show that there is close agreement for specific element leach rates between the modified IAEA test and the SPCF test at $25^{\circ} \mathrm{C}$. Despite these encouraging results, the fact remains 
that the IAEA test does not model repository conditions; therefore, it is recommended that this test not be used as the sole source of leaching data.

The static leach test models the condition of near-zero flow in a repository and provides information on element readsorption and solubility limits. The SPCF test is used to study the effects of flowing solutions at velocities that may be anticipated for geologic groundwaters within breached repositories. These two testing methods, coupled with the use of autoclaves, constitute the current thrust of WRIT leach testing, both for waste/solution and waste package interactions with host rocks and their associated ground water. 


\section{CONTENTS}

SUMMARY AND CONCLUSIONS

FIGURES

TABLES

ACKNOWLEDGMENTS .

INTRODUCTION

MODIFIED IAEA LEACH TEST

BACKGROUND

WRIT-MODIFIED IAEA LEACH TEST PROCEDURE . $\quad$ • $\quad$ •

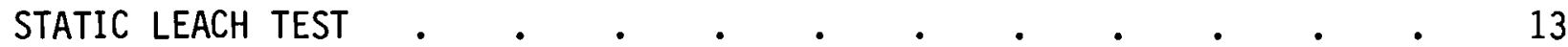

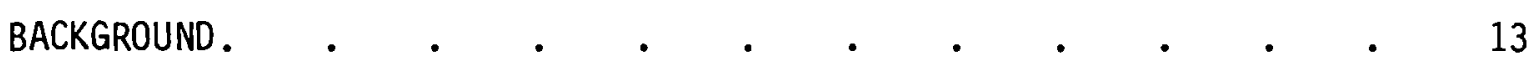

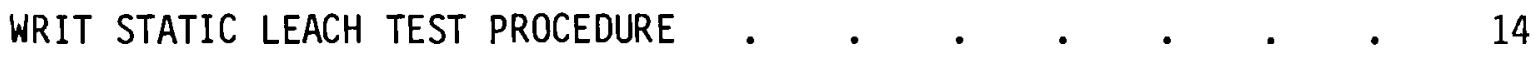

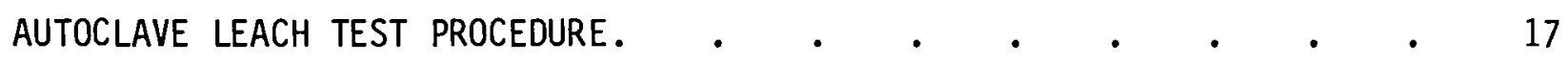

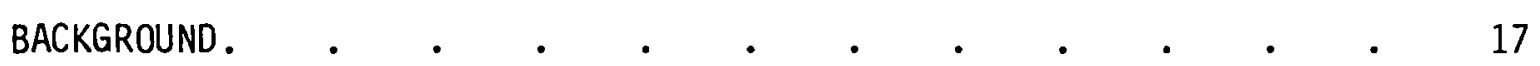

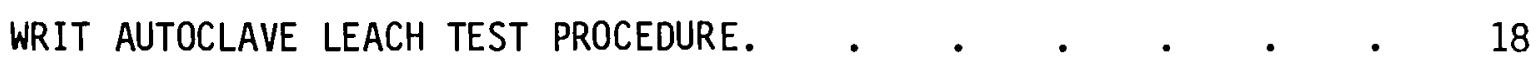

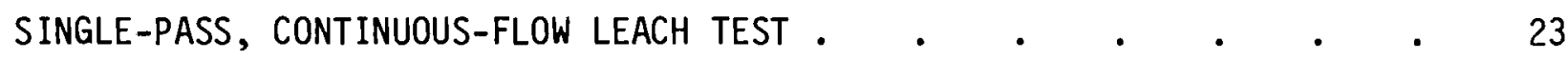

BACKGROUND. $\quad . \quad . \quad . \quad . \quad . \quad . \quad . \quad . \quad . \quad . \quad 23$

SINGLE-PASS, CONTINUOUS-FLOW LEACH TEST PROCEDURE . • • • • 26

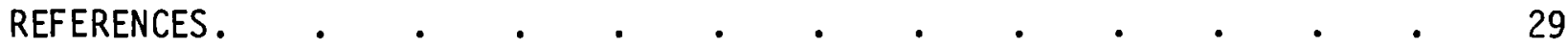



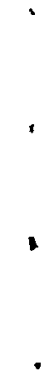


\section{FIGURES}

1 Modified IAEA Leach Test Apparatus . . . . . . 8

2 Waste Form Spec imen Holder for Modified IAEA Leach Test. . $\quad 9$

3 Neptunium Leach Rates from Modified IAEA and Single-Pass, Continuous-Flow Methods . . . . . . . . . 10

4 Static Leach Test Apparatus . . . . . . . . $\quad$. 15

5 Autoclave Leach Test Sample Container . . . . . . 18

6 Autoclave System for Simulated and Radionuclide-Doped Waste

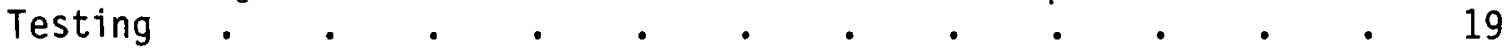

7 Autoclave for Hot-Cell Testing. . . . . . . . 20

8 Single-Pass, Continuous-Flow Leach Test System . . . . 24

9 Single-Pass, Continuous-Flow Leach Test Cell . . • • 25

TABLE

1 Current Status of WRIT Leach Tests . . . . . . . 2 



\section{ACKNOWLEDGMENTS}

We gratefully acknowledge the assistance of R. P. Turcotte, J. H. Westsik, Jr., Y. B. Katayama, C. O. Harvey, and R. D. Peters of the Pacific Northwest Laboratory, and H. C. Weed and J. Tewhey of Lawrence Livermore Laboratory for the ir assistance in the formulation of nuclear waste form leaching procedures.

This research is supported by the Waste/Rock Interactions Technology Program, (a) which is being conducted by the Pacific Northwest Laboratory. The program is sponsored by the Office of Nuclear Waste Isolation, managed by Battelle Memorial Institute for the U.S. Department of Energy under Contract DE-AC06-76RLO 1830.

(a) On October 1, 1979 the Waste Isolation Safety Assessment Program (WISAP) became the Waste/Rock Interactions Technology (WRIT) Program and the Assessment of the Effectiveness of Geologic Isolation Systems (AEGIS) Program. The tests reported in this document were started under the WISAP program and are continuing under the WRIT program, which issued this report. 

.

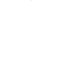




\section{INTRODUCTION}

As part of continuing studies on waste management sponsored by the Department of Energy (DOE), the Pacific Northwest Laboratory (PNL) ${ }^{(a)}$ has been conducting the Waste/Rock Interactions Technology Program (WRIT) for the Office of Nuclear Waste Isolation (ONWI). The purpose of this program is to gather and interpret data on the release and subsequent migration of radionuclides in the event nuclear-waste forms stored in a geologic repository come into contact with groundwater.

Information concerning the release of radionuclides from candidate nuclear-waste forms and waste packages is needed to evaluate deep geologic disposal concepts. Contact of nuclear wastes by groundwater is the most likely process whereby radioisotopes may be made available for transport (de Marsily et al. 1977; U.S. Environmental Protection Agency 1978; National Research Council 1978; Bredehoeft 1978). Through several different laboratory testing techniques, elemental leach data were obtained for interpretation and assessment of waste form/solution interactions.

This report describes the laboratory testing techniques that are being used by the WRIT program to investigate leaching characteristics of high-level and transuranic nuclear-waste forms. Leach tests are used to determine radionuclide or element release rates. We use the term "radionuclide release" to be the sumation of the concentration of the radionuclide solution plus the amount of the radionuclide adsorbed on the walls of the container used to conduct the leach test. The following tests are being used to 1) gather elemental release rate data for safety assessments, 2) provide leach solutions for sorption studies, and 3) provide leached waste forms for detailed surface characterization:

- a modified version of the IAEA's proposed standard leach test (Hespe 1971)

- a static leach test

- an autoclave leach test

- a single-pass, continuous-flow leach test.

(a) Pacific Northwest Laboratory is operated for the U.S. Department of Energy by Battelle Memorial Institute. 
The waste forms are characterized before any of these tests are conducted. This includes determining the chemical composition, radionuclide composition and homogeneity of the waste form. Samples are kept of each waste form tested.

These tests attempt to simulate the range of temperatures and flow conditions that may be encountered in a repository. They are not currently being used to model specific repository conditions or to describe waste package (waste form, canister, engineered barrier, backfill, host rock) performance. However, in the WRIT program, procedures and methodologies for performance tests on waste packages are being formulated at this time. Table 1 shows the current status of WRIT leach tests.

\section{TABLE 1. Current Status of WRIT Leach Tests}

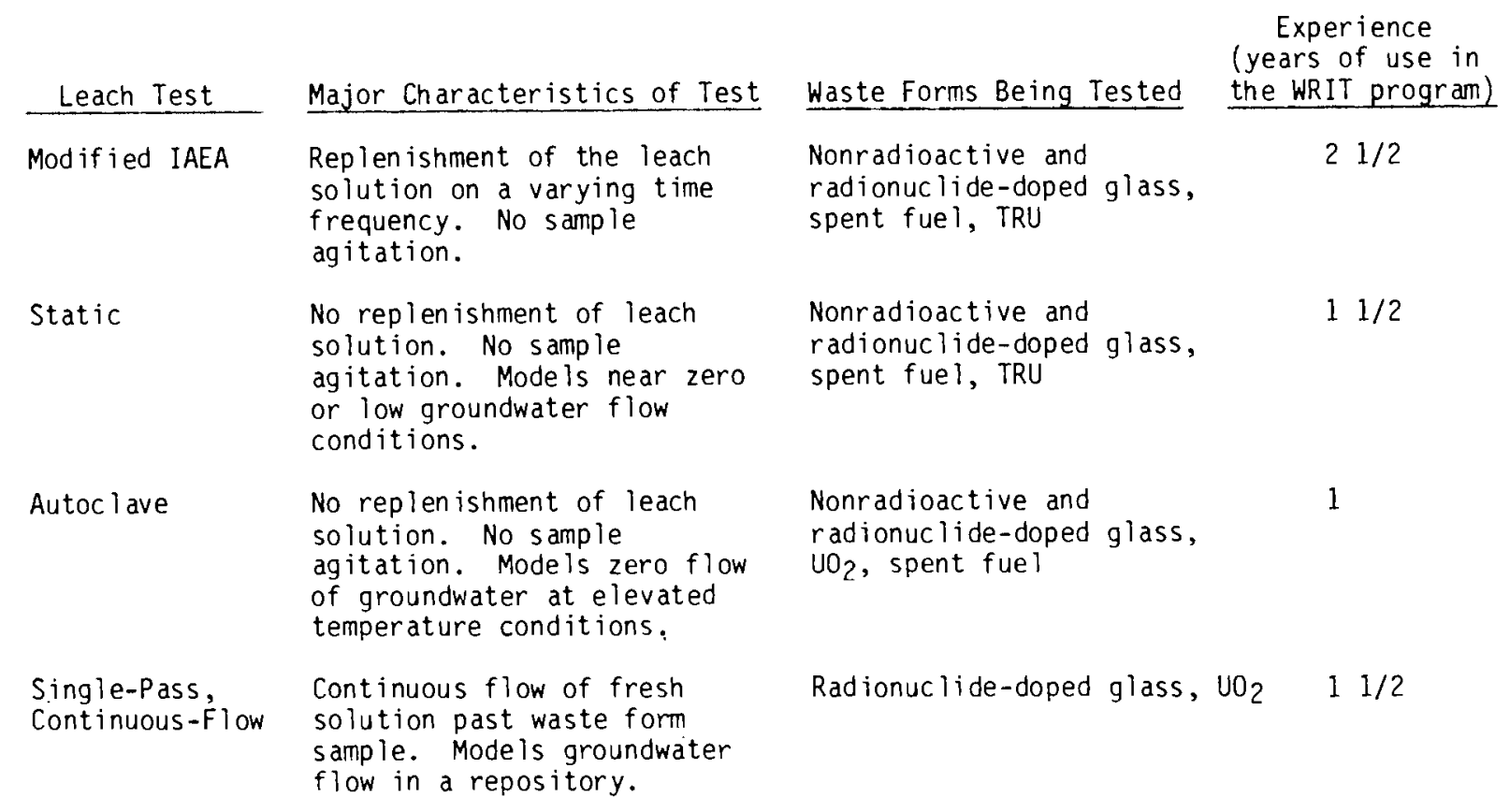

Currently for the WRIT program modified IAEA and single-pass, continuousflow leach tests, we are reporting the results in terms of an incremental leach rate or a cumulative fraction leached. Static leach tests results will be reported in terms of time-dependent solution concentrations. The equations used to calculate these are as follows: 
1. Incremental Leach Rate (ILR)

$$
I L R=\frac{A_{n}}{A_{0} \cdot S \cdot t}
$$

where

$$
\begin{aligned}
t= & \text { leaching time in days } \\
A_{n}= & \text { activity of a radionuclide (disintegrations/min) or amount } \\
& \text { (grams) of a given element in the leach solution and adsorbed on } \\
& \text { leach container walls after leach time } t \\
A_{0}= & \text { specific activity of a radionuclide (disintegrations/min-gram) or } \\
& \text { amount (grams/gram) in the specimen being leached } \\
\mathrm{S}= & \text { geometric surface area of sample, } \mathrm{cm}^{2} .
\end{aligned}
$$

2. Cumulative Fraction Leached (CFL)

$$
C F L=\frac{\sum_{n}^{A}}{A_{0}}
$$

where

$A_{n}$ is summed over the incremental leach times.

3. Time-Dependent Solution Concentration (TDSC)

$$
\operatorname{TDSC}=\frac{A_{n}}{A_{0} \cdot S}
$$

This method of reporting data from static tests utilizes one sample for each leach time and is therefore not cumulative.

This report gives the background of each testing method and describes the procedure used. It is intended that others may adopt these tests to standardize current and future data collection and/or may suggest areas that could be improved or alternative methods. 



\section{MODIFIED IAEA LEACH TEST}

\section{BACKGROUND}

In August 1969, two leach test methodologies applied to immobilized radioactive waste solids were drafted by a panel of experts convened by the International Atomic Energy Agency (IAEA). The first was called the "Intercomparison Method" and the second, the "Environmental Method." These methods were proposed as standard leaching tests by Hespe (1971). The procedures for the Intercomparison Method are described below:

1. The leach sample is made in a specific cylindrical size, according to radiation level, with height equal to diameter.

2. The sample is leached in the container that it is made in. Only the top surface of the waste form contacts the solution. The waste form adheres to but does not react with its container mold. In the case of a concrete container, the specimen is removed from its preparation canister and coated, except for the top surface, with a water-proof compound that adheres to the surface.

3. The leach solution is deionized water of not more than $1.5 \mu \mathrm{mho} / \mathrm{cm}$ conductivity.

4. The sampling frequency is:

- daily for the first week (or until the leaching rate is virtually constant, or until the $\mathrm{pH}$ of the leachate rises above 8.0)

- weekly for the next 8 wk

- monthly for the next 6 mo

- twice per year thereafter.

5. At the sampling time, the leach solution is decanted into another container which is sent for analyses. The solid waste specimen is then covered with a fresh volume of leachate and the test continues.

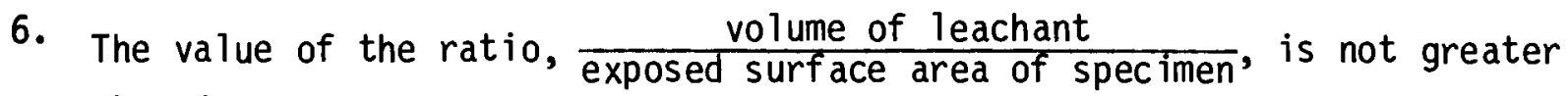
than $10 \mathrm{~cm}$. 
7. The temperature is $25^{\circ} \pm 5^{\circ} \mathrm{C}$.

8. There is no agitation of the leach solution or the waste specimen between sampling times.

9. The leaching container does not interact with the leachate solution.

The "Environmental Method" differed from the "Intercomparison Method" only in that:

- Water from the disposal environment was to be used instead of deionized water.

- The chemical composition, $\mathrm{pH}$, and chemical oxygen demand (COD) were to be determined for the leach solution.

- The duration of performing daily samplings was not to be changed when the $\mathrm{pH}$ rose above 8.0 .

The "modified IAEA" test procedure used by WRIT differs with respect to items 1 through 5 above; items 6 through 9 remain the same. The "modified IAEA" test used for the WRIT program entails the following:

1. The waste specimen to be leached is not required to be a specific size or shape. For spent fuel, a sieved fraction of +8 mesh is used. Detailed photographs are taken to estimate as closely as possible the geometric surface area. For waste glass a replicable procedure for making hemispherical beads is used to provide specimens for leaching. Details of this procedure are available in other reports (Bradley, Harvey and Turcotte 1979; Burkholder et al. 1979).

2. The waste sample itself is leached without the presence of its preparation canister or mold. The waste sample is suspended in the middle of the leach solution in a nylon basket attached to the lid of the leach container. The basket is to have the largest possible open weave to provide minimal contact with the sample and yet prevent the sample from falling through the openings in the basket weave.

3. Any leach solution can be used as long as it is characterized prior to contact with the waste sample. Characterization includes chemical 
composition and $\mathrm{pH}$. Eh measurements before and after leaching were once included, but since no changes have been detected in a variety of solutions after a 1-yr leaching time, the measurements are no longer routinely taken.

4. The modified sampling frequency is:

a. Daily for the first 4 days

b. Weekly for 8 wk

c. Monthly until the test is stopped. Although the effect of monthly changes in sampling frequency seem to have a minor effect on leach rate (Bradley, Harvey and Turcotte 1979), there was a pronounced effect on leach rates in earlier tests where a semi-annual sampling frequency was used (Bradley 1978).

5. During sampling times, the specimen holder is removed from the solution and placed in an equivalent amount of fresh solution in a new leaching container, which allows an analysis of the elements adsorbed onto the walls of the leaching container. A more detailed account of the steps taken in the WRIT-modified IAEA test follows.

Figure 1 shows the apparatus used at PNL for the modified IAEA leach test. Figure 2 shows a close-up photograph of an actinide-doped waste glass specimen nolder.

The above WRIT-modified version of the IAEA leach test was used in the first series of leach tests started in the WISAP program (Burkholder et al. 1979). The original intent was to gather comparative leach data and not to closely model anticipated repository conditions or to provide conclusive data for the elucidation of leaching mechanisms. The semi-annual sampling frequency was changed because a study using fully radioactive glass showed that the semiannual sampling frequency did have a large effect on the observed leach rate (Bradley 1978). Also, to keep costs and analysis time within reason, the longest sampling frequency was set at 1 mo. A progress report on the results of this test to date using waste glass doped with technetium and various actinides has been reported (Bradley, Harvey and Turcotte 1979). 


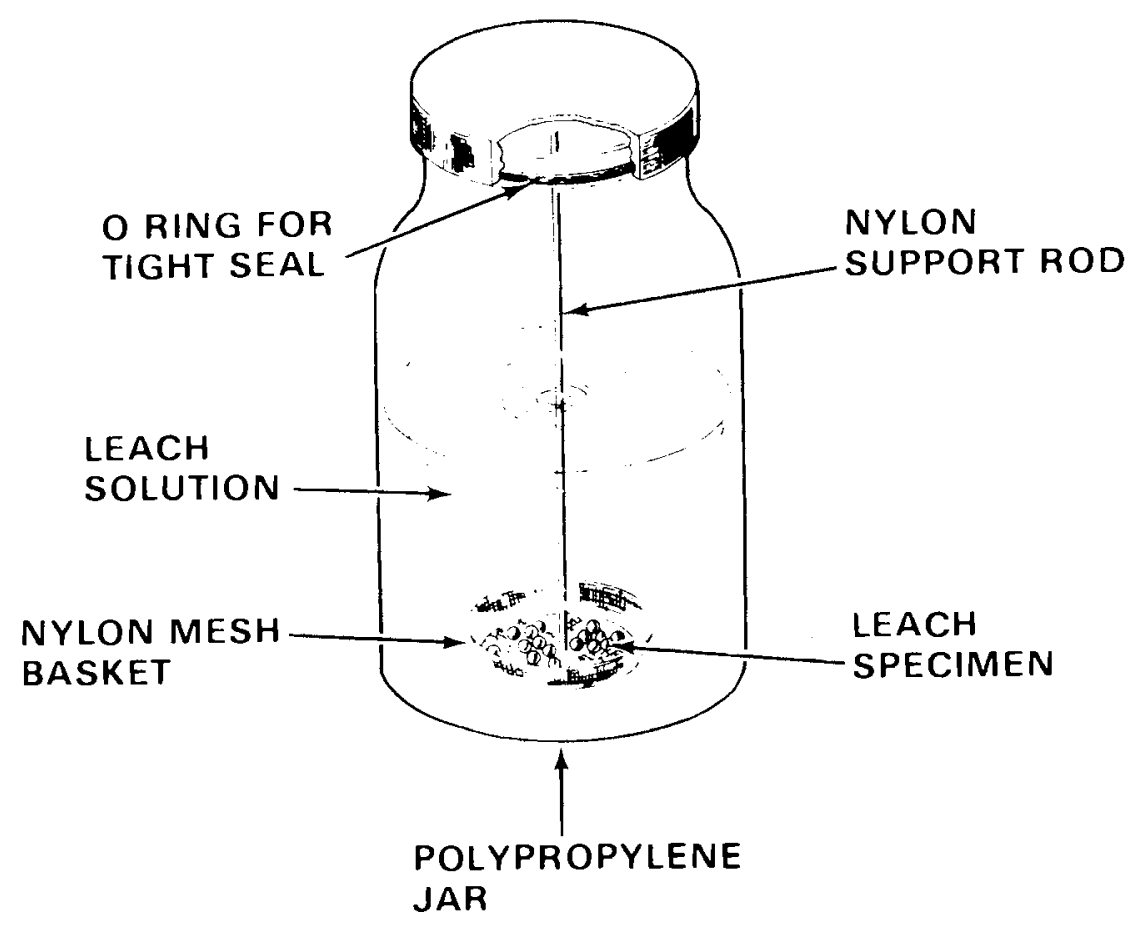

FIGURE 1. Modified IAEA Leach Test Apparatus

Although some of the actinide leach rates (plutonium and neptunium in particular) appeared to be affected by sample frequency, the effect is not large. Also, no effect has been noted for the primary glass matrix element silicon. A comparison between the WRIT-modified IAEA test and a true single-pass, continuous-flow solution flow test conducted at Lawrence Livermore Laboratory has been made. The same waste form materials (both tests used waste glass made during a single run at PNL), and the same leach solutions were used. Solution was flowed past the waste glass (details of this test start on page 23) at the same "effective" rates seen in the modified IAEA test for a daily, weekly, and monthly sampling frequency. The results to date (Weed et al. 1979) show close agreement in leach rates for both $\mathrm{Np}$ and $\mathrm{Pu}$. Figure 3 shows this agreement for neptunium release from 76-68 waste glass in 0.03M sodium bicarbonate solution. Thus, it appears that: 1) the WRIT-modified IAEA test does not yield results that are significantly different from a true flow test under the conditions studied, and 2) the WRIT-modified IAEA test appears to give adequate results for comparative purposes. 


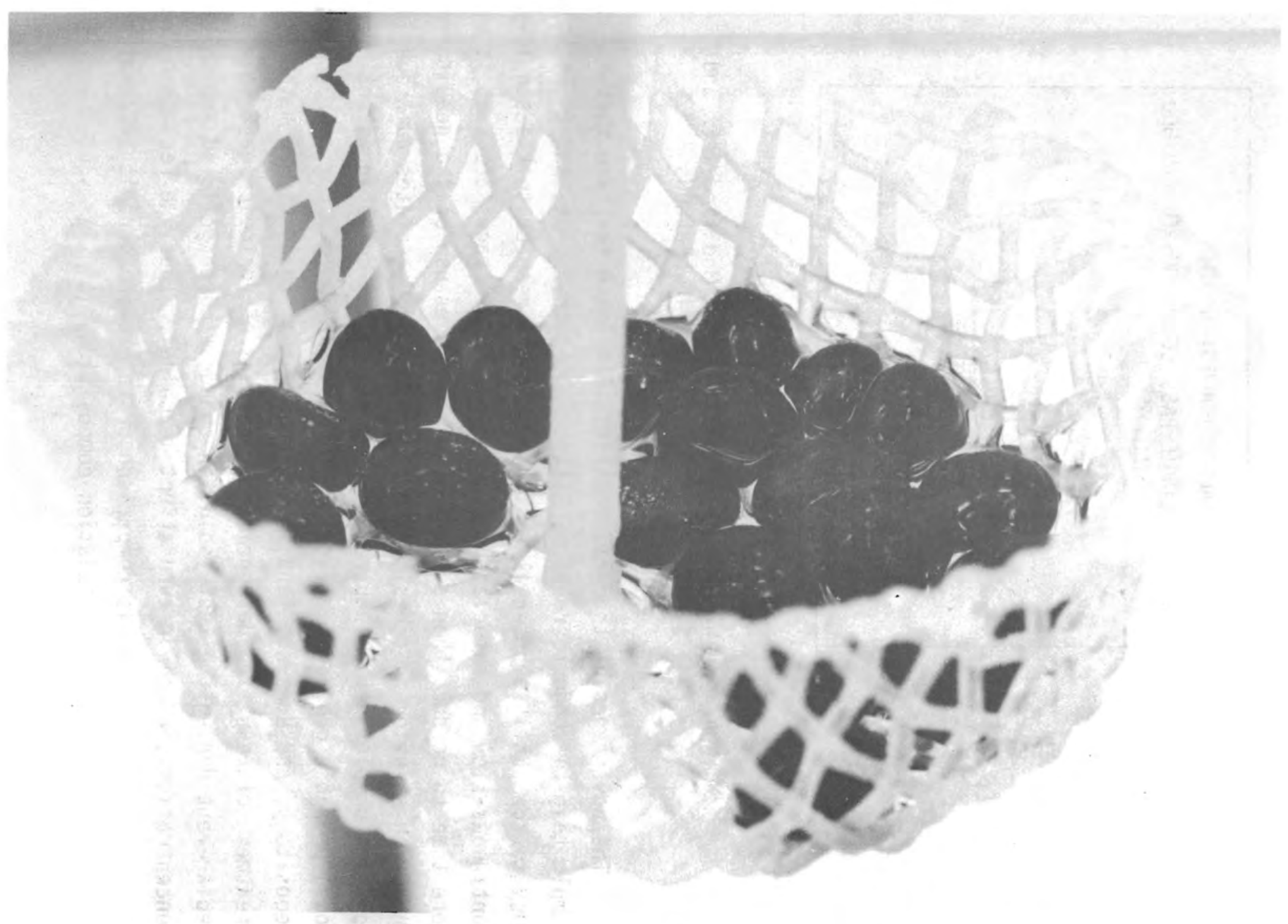

FIGURE 2. Waste Form Specimen Holder for Modified IAEA Leach Test 


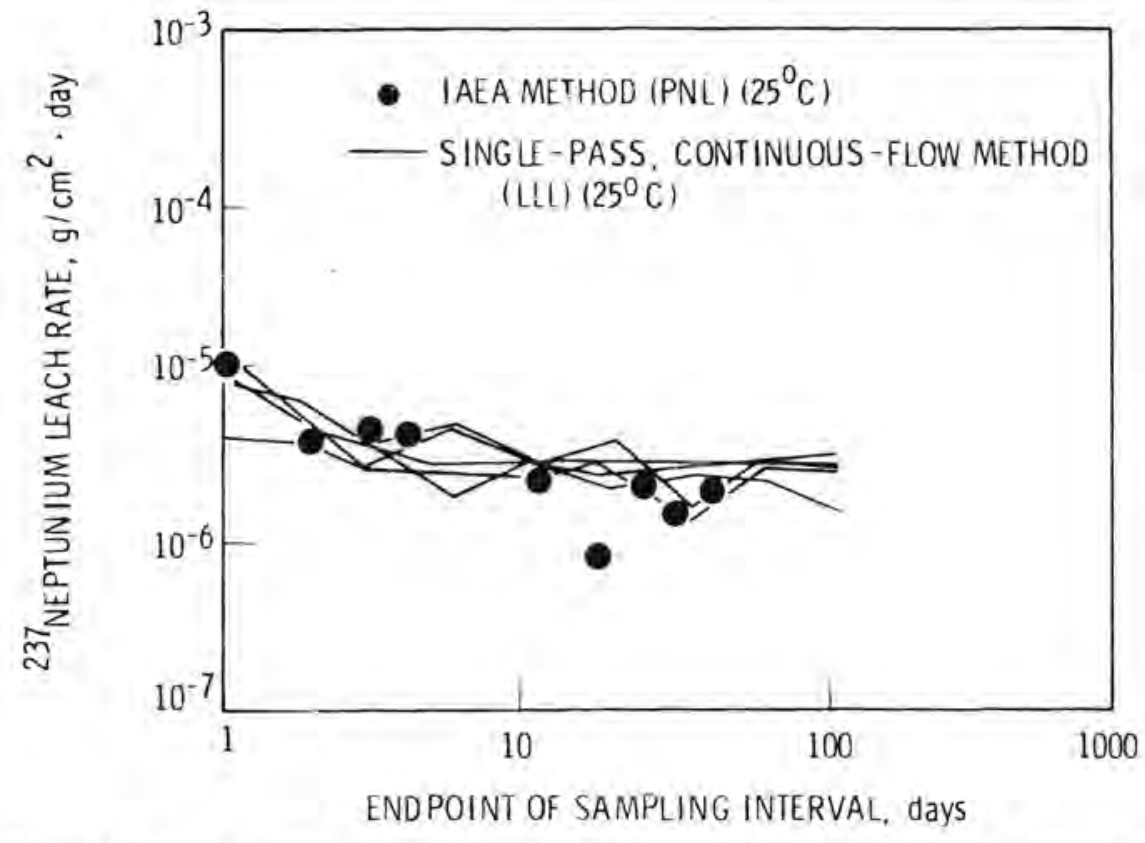

FIGURE 3. Neptunium Leach Rates from Modified IAEA and Single-Pass, Cont inuous-Flow Methods

The advantages of the WRIT-modified IAEA leach test are that it is a simple test to conduct, requires little laboratory space, and is relatively easy to conduct in a hot-cell environment (with respect to the single-pass, continuous-flow and autoclave tests). The disadvantages are that it requires more time to conduct than a static leach test because of the need to replenish the leach solution on a designated time schedule; generates numerous leach solution samples, thus incurring higher analytical costs; does not correctly mode 1 probable groundwater flow conditions that could occur in a geologic repository; and does not lend itself easily to mechanistic or mathematical treatment of resulting data primarily because of periodic leach solution replacement during the test (solution changes cause cyclic pH and solution concentrations, which in turn affect leaching). Thus, we recommend that the test be used for materials comparison or to provide generic information on parameter effects such as solution composition. 
WRIT-MODIFIED IAEA LEACH TEST PROCEDURE

Note: To facilitate document control, the experimenter is required to record al1 information regarding the leach test in registered log books. This procedure is common to all of the WRIT leach tests.

1. Leach solutions are made up in 10-1iter batches using reagent-grade chemicals and deionized water, and are stored in polypropylene containers. Following solution makeup, samples are taken for analys is of pH, conductivity (on deionized water) and chemical composition by inductively coupled plasma spectroscopy (ICP) (early samples were analyzed by spark source mass spectroscopy).

2. Prior to placing the waste form sample in its basket, the sample is washed with methanol or acetone to remove surface-adhering fine particles and dried. The sample is weighed and its dimensions measured and recorded to enable the geometric surface area to be calculated.

3. Wide-mouthed polypropylene bottles are used and waste form sample sizes are chosen such that the waste sample may be placed in the middle of the leach solution with ease.

4. The waste sample is placed in its holding basket, the proper amount of solution is added to the bottle to provide a leach solution volume to waste form geometric surface area ratio of $10 \mathrm{~cm}^{3} / \mathrm{cm}^{2}$.

5. The waste specimen basket is carefully lowered into the solution-filled bottle, the lid is tightened, and the apparatus is placed into a holding rack.

6. At designated times the bottle is removed from the holding rack and the lid carefully removed. The waste specimen basket (with attached lid) is placed into a fresh leach solution in a new bottle, and returned to the holding rack.

7. The solution in the leach container is swirled and the following samples are removed:

a. One sample is removed via disposable pipet and placed into a polypropylene bottle and acidified with 100kl of ultra-pure nitric acid 
per $10 \mathrm{ml}$ of solution. This procedure has been shown to prevent radionuclides adhering to container walls (Bradley et al. 1979). This aliquot is used for counting alpha, beta, and gamma emitters.

b. Another sample is placed into a polypropylene container and is not acidified. This sample is used for $\mathrm{pH}$, conductivity (in the case of deionized water), silicon analyses, and ICP analysis of elemental composition.

c. The remaining solution may be used for radionuclide sorption/rock studies, or be discarded via the appropriate waste solution handling procedures.

8. Since many (if not all) of the radionuclides being studied adsorb to some degree on the leach container wall, the following steps are taken to determine the extent of this adsorption:

a. An aliquot of $5 \mathrm{M} \mathrm{HNO}_{3}+0.05 \mathrm{M} \mathrm{HF}$ solution (reagent acids added to deionized water) is added to the now empty leach container. A volume equal to the original leach solution volume is added.

b. The solution is allowed to stand in the leach container for 1 wk. After this time an aliquot is taken and placed in a polypropylene bottle and submitted for alpha, beta, and gamma analyses.

c. The results of the analyses from $8 \mathrm{~b}$ are added to those from $7 \mathrm{a}$ to yield the total release of a given radionuclide from the waste form spec imen.

d. The leach bottle and remaining acid wash solution are then discarded via the appropriate waste handling procedures. 


\section{STATIC LEACH TEST}

\section{$\underline{\text { BACKGROUND }}$}

Within a year from the start of the WRIT-modified IAEA leach test, three other tests were started to gain specific information on parameter effects and to model more closely anticipated repository conditions. One of these tests was the static leach test. As the name implies, no sample agitation, solution flow, or solution replenishment is involved. To avoid potential difficulties with periodic removal of only a small leachate sample for analyses, the tests were designed such that a series of replicates, started at the same time, would serve as the complete test series over time. When a sampling time was reached, one replicate would be sacrificed for analysis.

The static tests were initiated to investigate the effects of increasing solution radionuclide and matrix element concentration as well as re-adsorption reactions on radionuclide release rates. The advantages of the static leach test are that it is the easiest test to conduct and simulates near-zero or very low groundwater flow in a repository. The static test also allows study of the approach to solubility limits for various radionuclides and matrix elements, which is important in determining thermodynamic solubility constraints. The test is also easily adopted to hot-cell environment operation and requires minimal work space. Possible problems when using plastic leach containers are solution loss, container material/leach solution interactions, and container degradation when running the tests for long times $(>1 \mathrm{yr})$ at temperatures near $100^{\circ} \mathrm{C}$. These problems can be overcome by utilizing welded gold or platinum capsules, but the cost becomes prohibitive. Possibilities for improving the long-term aspects of the static test are to use Teflon ${ }^{\circledR}$ containers or double containers. However, these possibilities have not been verified.

The procedures for the static leach test borrow a good deal from the previously discussed modified IAEA leach test in terms of:

- sample sizes

- leach container specifications

- solution analyses

- leach solution volume to sample geometric surface area ratio. 


\section{WRIT STATIC LEACH TEST PROCEDURE}

1. Since the solutions are not changed and all tests are started at the same time, a large enough solution batch is prepared to supply all of the tests. Following solution makeup, samples are taken for analys is of $\mathrm{pH}$, conductivity, and chemical composition.

2. Prior to placing the waste form sample in the leach container, the sample is washed with methanol or acetone to remove surface-adhering fine particles and dried. The sample is weighed and its dimensions measured and recorded to enable a geometric surface area to be calculated.

3. Since the solution is not changed during any leach time interval, the waste specimen is not held in a basket. Rather, the specimen is placed on the bottom of the leach test container, and leach solution is slowly added.

4. For the tests using radionuclide-doped waste forms that can be handled outside a remote facility, polypropylene bottles are used. It is recommended that for long times $\left(>1 \mathrm{yr}\right.$ ) or temperatures greater than $50^{\circ} \mathrm{C}$, that Teflon ${ }^{\circledR}$ containers be used. For tests with spent fuel, fused silica jars with flat-ground, fused silica lids are being used. The weight of the container and contents before and after the test is measured to check whether slow leakage or evaporation has occurred. Figure 4 shows the type of apparatus being used.

5. Since our static tests are located in an area with insufficient building temperature control, controlled temperature baths are used $\left( \pm 1^{\circ} \mathrm{C}\right)$.

6. At designated sample times a leach test container is removed from the temperature bath and the following steps are taken:

a. A solution sample is removed via disposable pipet and placed into a polypropylene bottle acidified with 100ul of ultra-pure nitric acid per $10 \mathrm{~m} \ell$ of solution. This aliquot is used for counting alpha, beta, and gamma emitters.

b. Another sample is placed into a polypropylene container and is not acidified. This sample is used for $\mathrm{pH}$, conductivity, and ICP analysis of elemental composition. 


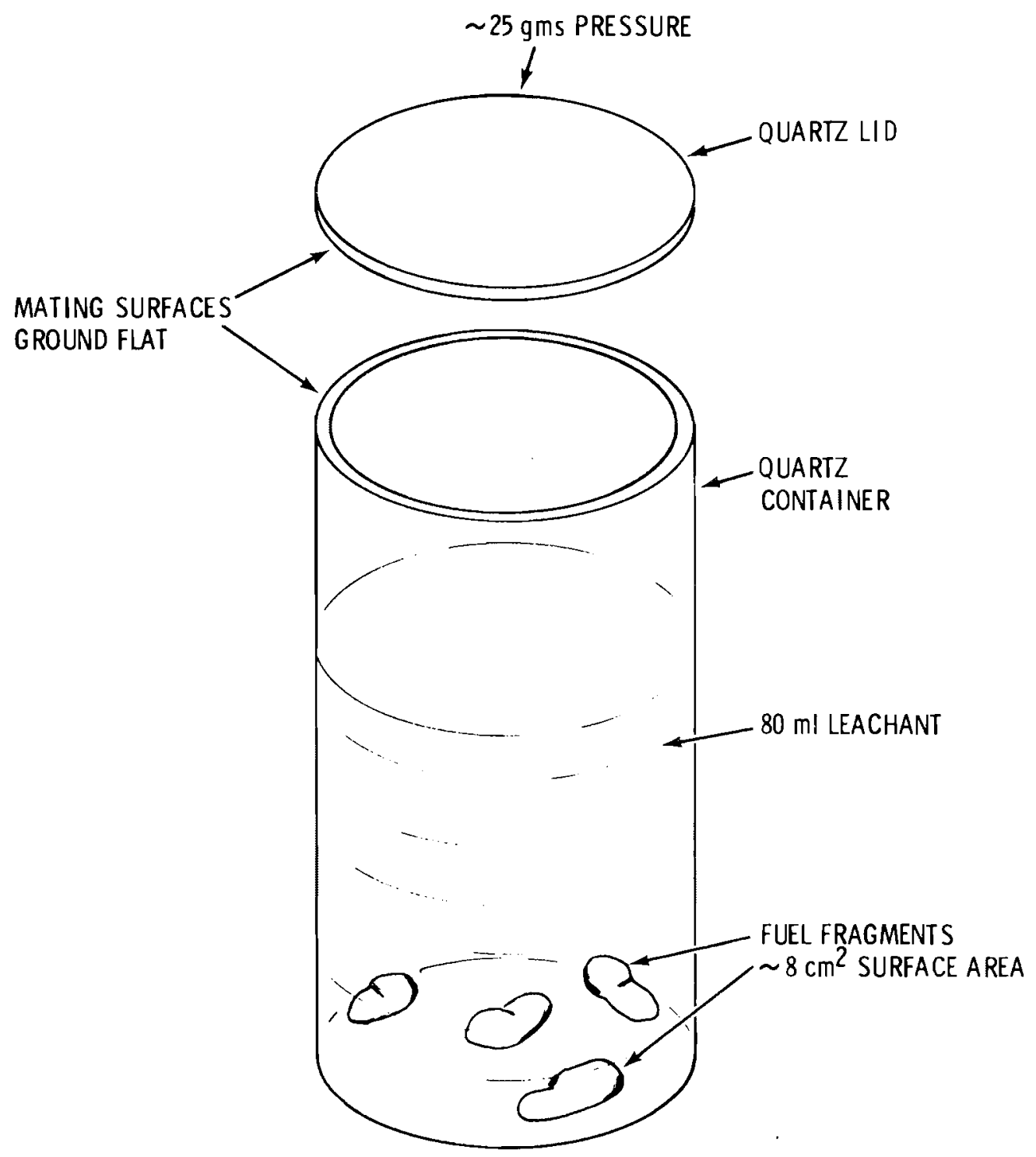

FIGURE 4. Static Leach Test Apparatus (Spent Fuel)

c. The remaining solution may be used for radionuclide/rock sorption studies or discarded via the appropriate waste solution handling procedures.

d. The waste specimen is removed from the container using forceps and is rinsed briefly (less than $30 \mathrm{sec}$ ) with 5 to $10 \mathrm{ml}$ of deionized water. 
e. The specimen is then placed into a clean, dry container, and undergoes surface analyses via scanning electron microscopy (SEM), Auger spectroscopy, and electron spectroscopy for chemical analyses (ESCA) or similar techniques.

7. Since many (if not al1) of the radionuclides being studied adsorb to some degree on the leach container. wall, the following steps are taken to determine the extent of this adsorption:

a. An aliquot of $5 \mathrm{M} \mathrm{HNO}_{3}+0.05 \mathrm{M} \mathrm{HF}$ solution (reagent acids added to deionized water) is added to the now empty leach container. A volume equal to the original leach solution volume is added.

b. The solution is allowed to stand in the leach container for 1 wk. After this time an aliquot is taken and placed in a polypropylene bottle and submitted for alpha, beta, and gamma analyses.

c. The results of the analyses from $7 \mathrm{~b}$ are added to those from $6 \mathrm{a}$ to yield the total release of a given radionuclide from the waste form specimen.

d. The leach bottle and remaining acid wash solution is then discarded via the appropriate waste handling procedures. 


\section{AUTOCLAVE LEACH TEST PROCEDURE}

\section{BACKGROUND}

In order to investigate the effect of temperature on radionuclide release at temperatures greater than $100^{\circ} \mathrm{C}$, autoclave equipment is being used in leaching of waste forms. The experimental temperature range covered on the WRIT program is from $25^{\circ}$ to $250^{\circ} \mathrm{C}$. The autoclave tests that have been conducted to date have been nonflowing or static leaching tests. Single-pass, continuousflow autoclave work is planned for future testing, and a hot-cell autoclave system has been designed which has flowing leach soiution capability. However, at this time a procedure has not been written for the continuous flow autoclave leach tests. Thus, the current autoclave leach test is simply a static leach test conducted at higher temperatures and confined by a pressure vessel. To reduce the time and operating costs by allowing several tests to be run at the same time, gold capsules are used for the waste form/solution interaction studies, including both spent fuel and waste glass. Direct solution sampling of autoclave experiments will be performed in future tests that do not use gold capsules; however, this discussion will be restricted to gold-encapsulated samples only. Figure 5 shows a gold leach test container used for autoclave testing. An autoclave system used for simulated and radionuclide-doped waste forms is shown in Figure 6 . Figure 7 shows an autoclave designed for hot-cell remote operations.

An advantage of autoclave tests is that they can simulate repository temperature and pressure conditions, and due to accelerated leaching at elevated temperatures, the tests are of shorter duration. Another advantage is that element solubility limits can be more rapidly achieved at the higher temperatures. However, autoclave tests have several disadvantages. They are the most expensive of leach tests, cannot easily handle large numbers of samples, require more laboratory space than the other leach tests and are not easily used in a hot-cell environment. The tests also require experienced personnel for operation and maintenance, and special safety precautions. 


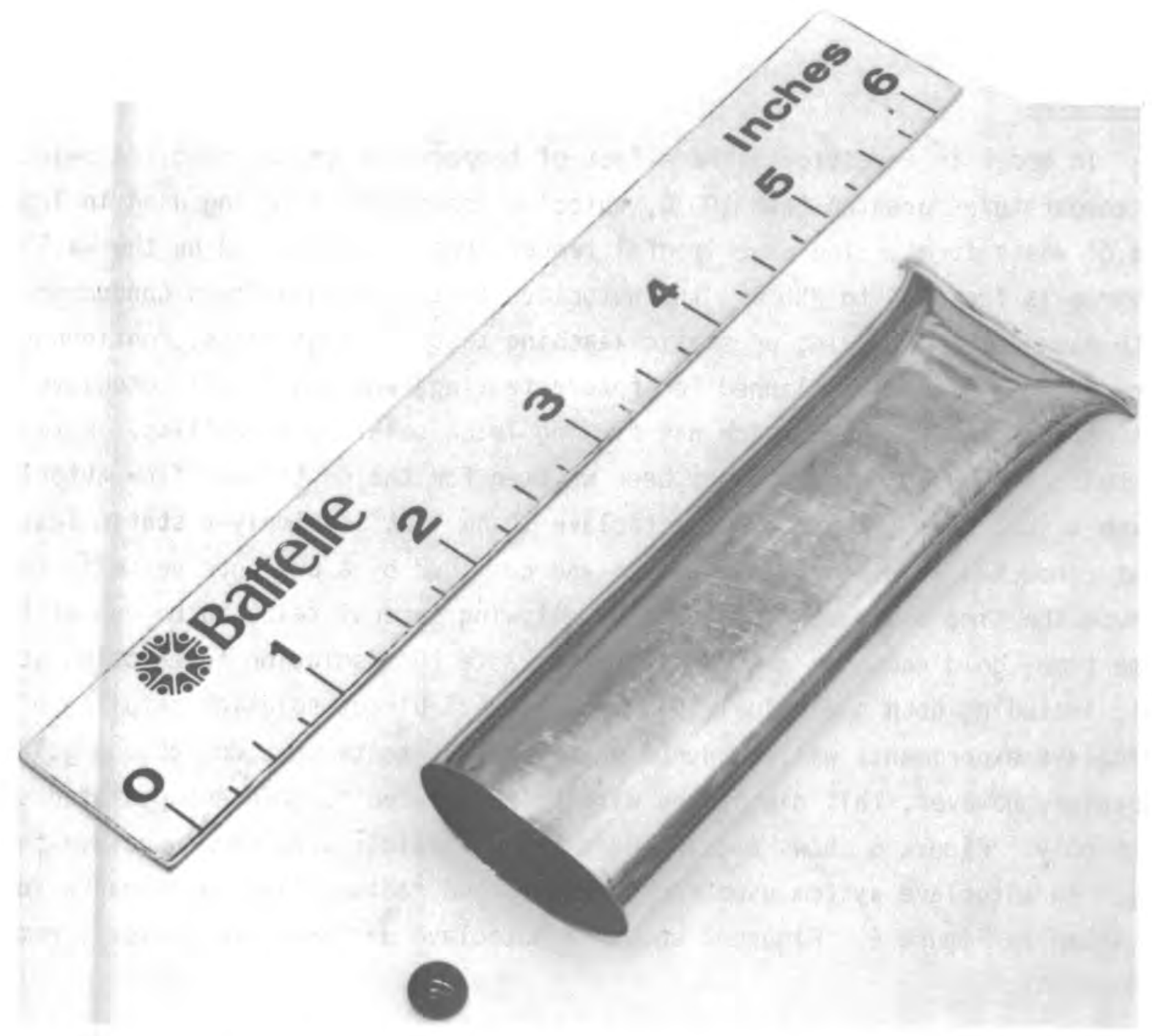

FIGURE 5. Autoclave Leach Test Sample Container

\section{WRIT AUTOCLAVE LEACH TEST PROCEDURE}

1. A large enough leach solution batch is prepared in order to supply all of the tests in a given series. Following solution makeup, samples are taken for analysis of $\mathrm{pH}$, conductivity, and chemical composition.

2. Prior to placing the waste form sample in the gold capsule, the sample is washed with methanol or acetone to remove surface-adhering fine particles and dried. The sample is weighed and its dimensions measured and recorded to enable a geometric surface area to be calculated. 


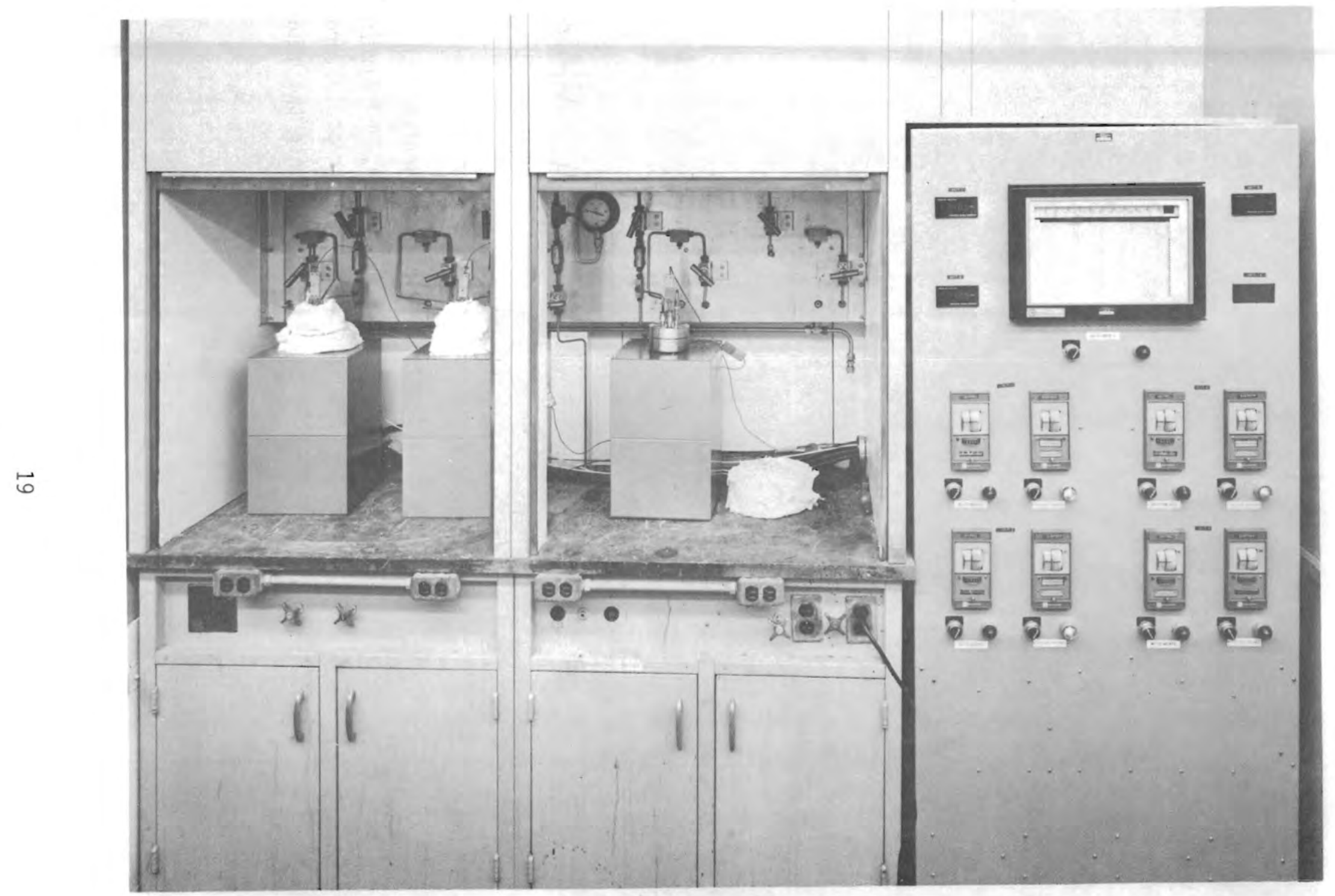

FIGURE 6. Autoclave System for Simulated and Radionuclide-Doped Waste Testing 


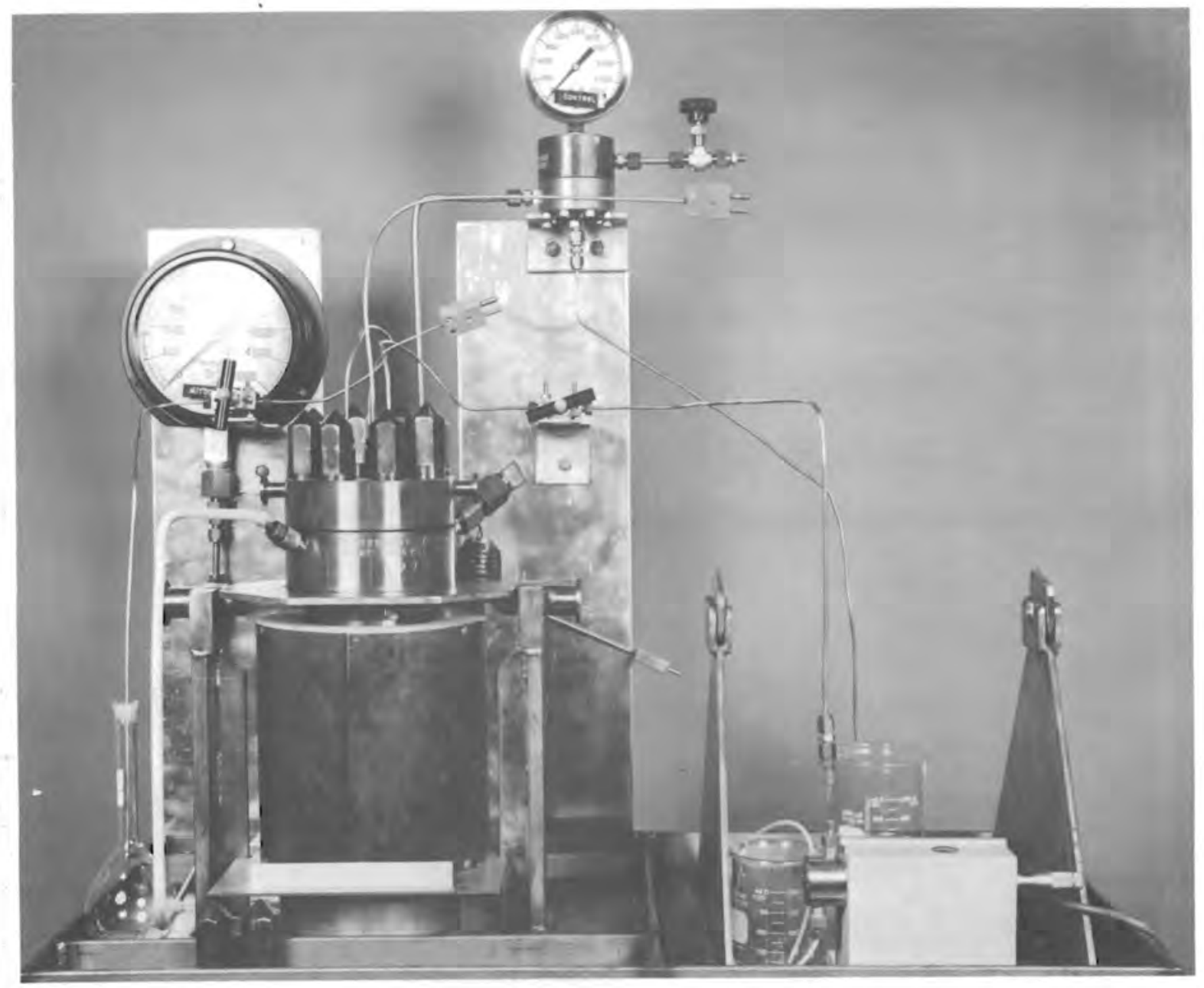

FIGURE 7. Autoclave for Hot-Cell Testing

3. Each gold capsule is cleaned by: 1) dipping it in concentrated nitric acid for $5 \mathrm{~min}, 2$ ) rinsing it in deionized water for $5 \mathrm{~min}$, and 3) rinsing it for an additional $5 \mathrm{~min}$ in fresh deionized water. The capsules are then dried and an identification code is lightly scribed onto the gold capsule.

4. Calculations are made to determine the amount of solution to add for a given waste sample size so that the solution volume-to-sample geometric surface area ratio is $10 \mathrm{~cm}^{3} / \mathrm{cm}^{2}$ at the specified operating temperature. 
5. The waste form sample is placed in the gold capsule, solution is added and the air above the solution is purged with argon for $1 \mathrm{~min}$. The top of the capsule is crimped with flat-headed pliers and is welded shut using a tungsten arc inert gas welder (TIG). The capsule is then weighed. The weld closure integrity is checked by vacuum leak checking.

6. The appropriate number of capsules are loaded into the autoclave, and the correct amount of deionized water is added. The autoclave is then sealed.

7. The autoclave is pressurized to 2000 psi using an inert gas. The autoclave is then heated rapidly to the desired operating temperature, and the pressure is maintained at $2000 \mathrm{psi}$. The time the autoclave heating started and the time the autoclave reaches the correct temperature are recorded. Temperature and pressure are maintained and monitored for the specified time period.

8. At the selected sampling time the autoclave is turned off and rapidly cooled to room temperature while the pressure at $2000 \mathrm{psi}$ is sti11 maintained. The pressure is reduced to ambient after the cooldown, and the time when the autoclave was turned off and the time the autoclave reached room temperature are recorded.

9. The autoclave is opened and the gold capsules are removed. A sample is taken of the external fluid (the deionized water added at the start of the test) and is sent immediately for chemical analyses (ICP).

10. The gold capsules are weighed and then carefully opened. After measuring $\mathrm{pH}$, the solution is decanted into a polypropylene bottle and is acidified with 100ul of ultra-pure nitric acid per $10 \mathrm{ml}$ of solution. This sample is sent for ICP analyses and radioisotopic analyses as required. If there is an adequate volume of solution resulting from the test, an un-acidified sample may be taken for radionuclide/rock sorption studies.

11. The inside of the gold capsule and the surface of the waste form specimen are visually examined for reaction products. If visible reaction products are present, they are removed, $\mathrm{placed}$ in a clean container and transferred for analyses, such as SEM/microprobe and photomicroscopy. 
12. The waste specimen is removed, dried and weighed, and then transferred for detailed surface analyses, SEM/microprobe, Auger, and ESCA as necessary.

13. The gold capsule is then filled with a solution of $5 \mathrm{M} \mathrm{HNO}_{3}+0.05 \mathrm{M} \mathrm{HF}$. After $24 \mathrm{~h}$, the solution is sampled and transferred for chemical analyses. The remainder of the solution is decanted, and the gold capsule is dried and weighed. 


\section{SINGLE-PASS, CONTINUOUS-FLOW LEACH TEST}

BACKGROUND

The complement to the static leach test is one that accurately meters the leaching solution as it passes the waste form sample. This type of test would more correctly model the condition of solution flow or convective migration through a repository. As part of the WRIT program, study of the effects of flow rate on radionuclide release is being conducted at subcontract was placed with Lawrence Livermore Laboratory (LLL).

The concept for a single-pass, continuous-flow (SPCF) leach test evolved at LLL when the need arose for a laboratory method to evaluate the release rate into groundwater of radionuclides from the melt glass produced during an underground nuclear explosion. Since groundwater invades the explosion cavity when detonations occur beneath the water table, a potential exists for this slowly flowing groundwater to leach radioactivity from the melt glass and carry it along to distant discharge areas.

Weed and Jackson (1979) first devised the SPCF concept in an attempt to reproduce these underground flow conditions in the laboratory and to assess realistically the stability of explosion melt glass, or candidate waste forms for nuclear waste disposal, to groundwater leaching and corrosion. The SPCF leach test concept is schematically illustrated in Figure 8. A low-volume peristaltic pump provides the solution metering and delivery from a supply carboy to the rest of the system. Small-bore plastic tubing is used to connect the various system components. The leaching cell contains the waste form of interest. Figure 9 is a cutaway view of an assembled cell. All internal components that the solution contacts are made of plastic to minimize element sorption and changes in solution chemistry. Filters can be used between the inlet and outlet filter grids to contain fine material. For coarser samples using only the filter grids allows more trouble-free solution flow through the ce11. As solution exits the cell, it is directed into plastic bottles. Solution is collected, and at predetermined intervals, removed from the system and analyzed for radionuclides and other elements leached from the waste form. 


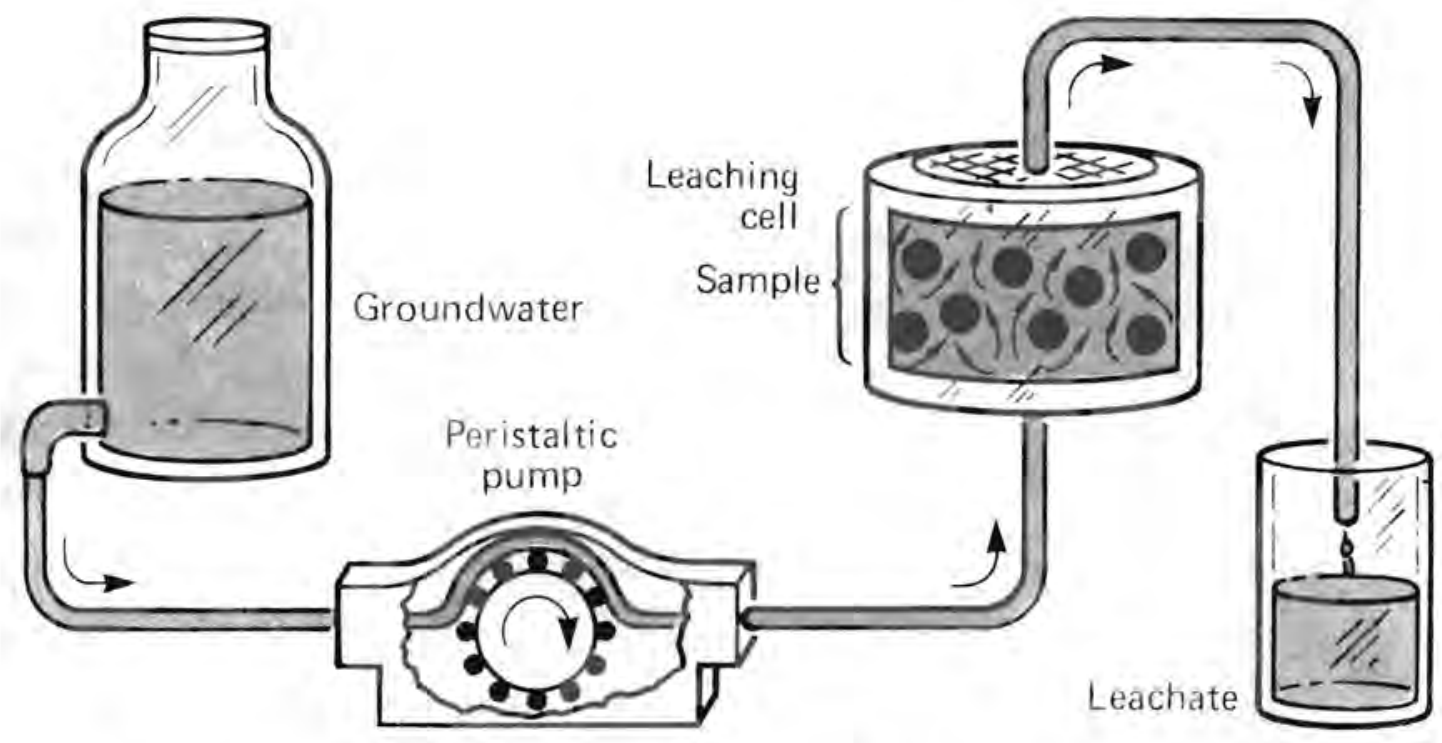

FIGURE 8. Single-Pass, Continuous-Flow Leach Test System

Several parameters can be studied simultaneously with this type of experiment. Solution compositions ranging from distilled water to saturated salt brine and temperatures of $25^{\circ}$ and $75^{\circ} \mathrm{C}$ have been used successfu11y. The flow rate can be varied over a wide range of values that are commonly found in natural aquifers, and a variety of waste forms can also be studied. In addition, it is possible to place candidate repository rock in contact with and downstream from the waste form. This type of test is currently being designed to assess the waste/rock groundwater interactions as we11 as the sorption of leached constituents directly onto the repository rock.

One advantage of the SPCF test is the close analogy to an actual flooded repository where groundwater is slowly flowing past the waste because of the natural hydraulic gradient. Peristaltic pumps and tubing (with a hole diameter as small as $0.13 \mathrm{~mm}$ ) are available, which will deliver a minimum volume flow rate of $1 \mathrm{ml} / \mathrm{d}$. This corresponds to an empty cell linear flow rate of $0.2 \mathrm{~cm} / \mathrm{d}$. As an example, an underground water velocity of $0.2 \mathrm{~cm} / \mathrm{d}$, or $0.72 \mathrm{~m} / \mathrm{yr}$, is less than the typical values of 2 to $76 \mathrm{~m} / \mathrm{yr}$ measured on eastern Pahute Mesa at the Nevada Test Site (NTS) (Blankennagel and Weir 1973). Consequently, actual flow rates encountered in nature can be reproduced in the laboratory using the SPCF leach test technology. 


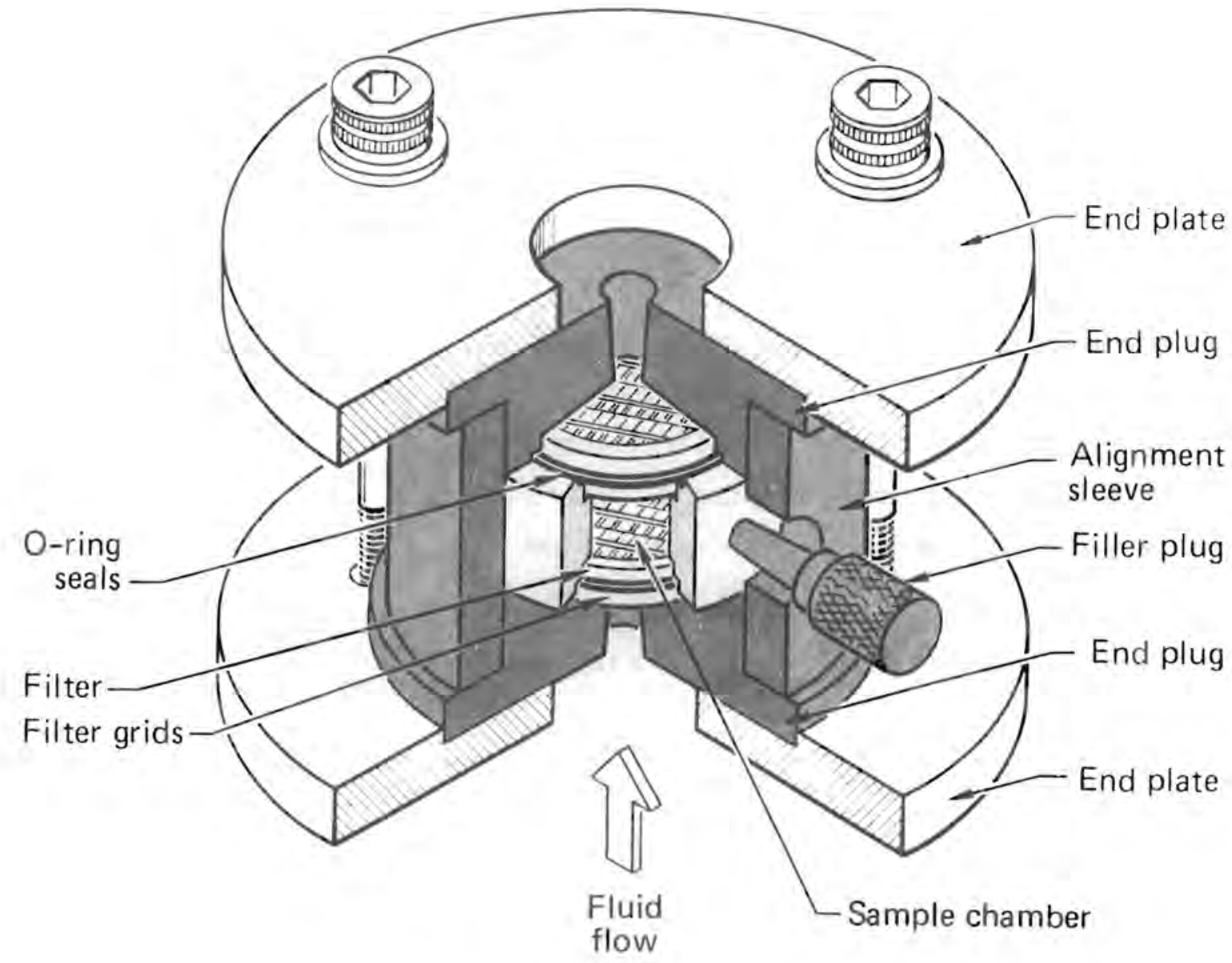

FIGURE 9. Single-Pass, Continuous-Flow Leach Test Cell

Another advantage is the ease of obtaining data regarding flow rate effects on leach rate. Flow rate is an important parameter because it is related to the total volume of water which contacts the waste form and may control the rate at which radionuclides can be leached from the waste form. Because candidate repositories will probably be located in a variety of groundwater velocity regimes, an understanding of the effect of flow rate on leach rate could become a key factor for evaluating probable repository performance.

The primary disadvantages of the SPCF method are increased complexity and expense when compared to the WRIT-modified IAEA and static leach tests. Pumps, hoses, cells and assembly time are required. The assembly, monitoring, and maintenance of the test requires experienced personnel. The test demands more 
laboratory space than the WRIT-modified IAEA or static leach test, and, like the autoclave test, the test is not easily adaptable to a hot-cell environment.

The SPCF test method only simulates conditions of a flooded repository after the thermal pulse from the waste has passed. That is, operating temperatures can only go as high as the ambient temperatures (below $100^{\circ} \mathrm{C}$ ) expected at moderate underground depth since the system operates only at one atmosphere pressure. This parameter is not a problem if, in the breached repository scenario being studied, the waste form canister remains intact until the thermal pulse has passed. If the canister is breached before this time, then hydrothermal leach tests must be used to understand the waste form stability under these higher temperature, groundwater flow conditions.

As has been previously discussed for the other tests, care is taken in the design of the experiment to choose materials having minimal chemical interactions or sorptive properties.

\section{SINGLE-PASS, CONTINUOUS-FLOW LEACH TEST PROCEDURE}

1. The leach solutions are made up in volumes as large as conveniently possible in order to reduce the number of batches needed if the test is to be run a long time period (up to $1 \mathrm{yr}$ ).

2. Prior to placing the waste form sample in the leach cell, the sample is washed with methanol or acetone to remove surface-adhering fine particles and dried. The sample is weighed and its dimensions measured and recorded to enable a geometric surface area to be calculated.

3. The leaching cell is assembled with the waste form (>2 $\mathrm{mm}$ in dia) of interest loosely packed between the filter grids. If finer-sized samples are used, the cell is assembled empty with small-pore membrane filters between each set of grids. The waste form samples are then introduced through the side port while applying a vacuum on the cell.

4. Using a syringe, the cells are filled with the appropriate leach solution and are immediately attached to the preset flowing system and placed into a temperature-controlled bath. The time is noted. 
5. The solution samples, collected in sample bottles downstream from the leaching apparatus, are removed according to a prearranged schedule.

a. One sample is placed into a polypropylene bottle and acidified with 100ul of ultra-pure nitric acid per $10 \mathrm{ml}$ of solution and is used for radioisotopic analysis.

b. Another sample is placed into a polypropylene container and is not acidified. This sample is used for pH, conductivity, and ICP analysis of elemental composition.

c. The remaining solution may be used for radionuclide/rock sorption studies or discarded via the appropriate waste solution handling procedures.

6. After the test has ended, a detailed analysis of the tubing and leach cell is carried out to determine the extent of any radionuclide adsorption on the container walls.

7. At the conclusion of the test, a waste form specimen is removed from the leaching cell using forceps and is rinsed briefly $(<30 \mathrm{sec})$ with 5 to $10 \mathrm{ml}$ of deionized water. The specimen is then placed into a clean, dry container. The specimen will then undergo surface analyses (SEM, Auger spectroscopy, ESCA). 


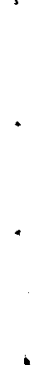




\section{REFERENCES}

Blankennagel, R. K. and J. E. Weir. 1973. "Geohydrology of the Eastern Part of Pahute Mesa, Nevada Test Site, Nye County, Nevada." USGS Professional Paper 712-B, U.S. Geological Survey.

Bradley, D. J. 1978. "Leaching of Fully Radioactive High-Level Waste Glass." PNL-2664, Pacific Northwest Laboratory, Richland, WA 99352.

Bradley, D. J., C. 0. Harvey, and R. P. Turcotte. 1979. "Leaching of Actinides and Technetium from Simulated High-Level Waste Glass," PNL-3152, Pacific Northwest Laboratory, Richland, WA 99352.

Bredehoeft, J. D., et al. 1978. "Geologic Disposal of High-Level Radioactive Wastes--Earth Sciences Perspectives." Geological Survey Circular 779.

Burkholder, H. C., et al. 1979. Waste Isolation Safety Assessment Program Technology Progress Report for FY-1977. PNL-2642, Pacific Northwest Laboratory, Richland, WA 99352.

de Marsily, G., et al. 1977. "Nuclear Waste Disposal: Can the Geologist Guarantee Isolation?" Science. 197(4303).

Hespe, E. D. (ed.) 1971. "Leach Testing of Immobilized Radioactive Waste Solids, A Proposal for a Standard Method." Atomic Energy Review. 9:1.

National Research Council. 1978. The Geological Criteria for Suitable Sites of High-Level Radioactive Waste Repositories. National Research CounciT, National Academy of Sciences, Washington DC.

U.S. Environmental Protection Agency. 1978. State of Geological Knowledge Regarding Potential Transport of High-Level Radioactive Waste From Deep Continental Repositories--Report of an Ad Hoc Panel of Earth Scientists. EPA-520-4-78-004. U.S. Environmental Protection Agency, Office of Radiation Programs, Washington DC.

Weed, H. C., et al. 1979. Leaching Characteristics of Actinides from Simulated Reactor Waste Glass, Part 2. University of California, Lawrence Livermore Laboratory, Livermore, CA 94550, and Pacific Northwest Laboratory, Richland, WA 99352, presented at the Materials Research Society meeting in Boston, MA, UCRL-81147, Part 2.

Weed, H. C. and D. D. Jackson. 1979. "Design of a Variable Flow-Rate, Single-Pass Leaching System." UCRL-52785, Lawrence Livermore Laboratory, Livermore, CA 94550. 


\section{DISTRIBUTION}

No. of

Copies

OFFSITE

A. A. Churm

DOE Chicago Patent Division 9800 South Cass Avenue

Argonne, IL 60439

27 DOE Technical Information Center

B. Adams

Corning Glass Works

Technical Staffs Division

Corning, NY 14830

Allied Chemical Corporation

(File Copy)

550 2nd Street

Idaho Falls, ID 83401

J. M. Batch

Battelle Memorial Institute

$505 \mathrm{King}$ Avenue

Columbus, $\mathrm{OH} 43201$

Battelle Memorial Institute

Office of Nuclear Waste

Isolation

Attn: Beverly Rawles

$505 \mathrm{King}$ Avenue

Columbus, $\mathrm{OH} 43201$

J. R. Berreth

Allied Chemical Corporation

550 2nd Street

Idaho Falls, ID 83401

R. E. Blanco

Union Carbide Corporation (ORNL)

Chemical Technology Division

P.0. Box $Y$

Oak Ridge, TN 37830

J. 0. Blomeke

Union Carbide Corporation (ORNL)

P.0. Box $Y$

Oak Ridge, TN 37830
No. of

Copies

Brookhaven National Laboratory

Reference Section

Information Division

Upton, NY 11973

R. A. Buckham

Allied-General Nuclear Service P.0. Box 847

Barnwe11, SC 29812

H. C. Burkholder

Office of Nuclear Waste Isolation

$505 \mathrm{King}$ Avenue

Columbus, $\mathrm{OH} 43201$

Wayne Carbiener

Office of Nuclear Waste Isolation

$505 \mathrm{King}$ Avenue

Columbus, $\mathrm{OH} 43201$

T. C. Chee

DOE Office of Nuclear Waste Management

Washington DC 20545

R. B. Chitwood

DOE Division of Nuclear Power Development

Washington DC 20545

5 D. Coles

Lawrence Livermore Laboratory

P.0. Box 808

Livermore, CA 94550

P. Colombo

Department of Applied Science

Brookhaven National Laboratory Upton, NY 11973

C. R. Cooley

DOE Office of Nuclear Waste Management

Washington DC 20545 
No. of

Copies

J. L. Crandall

E. I. duPont DeNemours and Company

Savannah River Laboratory

Aiken, SC 29801

R. E. Cunn ingham

Deputy Director for Fuels and Materials

Nuclear Regulatory Commission

Silver Springs, MD 20910

H. Diamond

Argonne National Laboratory

9700 South Cass Avenue

Argonne, IL 60439

J. P. Duckworth

Plant Manager

Nuclear Fuel Services, Inc.

P.0. Box 124

West Valley, NY 14171

J. 0. Duguid

Office of Nuclear Waste Isolation

505 King Avenue

Columbus, $\mathrm{OH} 43201$

Environmental Protection Agency

Technology Assessment Division (AW-559)

Office of Radiation Programs

Washington DC 20460

Keith Flynn

Argonne National Laboratory

9700 South Cass Avenue

Argonne, IL 60439

A. Friedman

Argonne National Laboratory

9700 South Cass Avenue

Argonne, IL 60439
No. of

Copies

R. G. Garvin

E. I. duPont DeNemours and Company

Savannah River Laboratory

Aiken, SC 29801

H. W. Godbee

Union Carbide Corporation (ORNL)

Chemical Technology Division

P.0. Box Y

Oak Ridge, TN 37830

E. S. Goldberg

DOE Savannah River Operations Office

P.0. Box A

Aiken, SC 29801

Mark Harwe 11

P.0. Box 667

Cannon Beach, OR 97110

C. A. Heath

DOE Office of Nuclear Waste

Management

Washington DC 20545

R. E. Heineman

Office of Nuclear Waste Isolation

$505 \mathrm{King}$ Avenue

Columbus, $\mathrm{OH} 43201$

L. L. Hench

Department of Materials Science and Engineering

University of Florida

Gainsville, FL 32611

H. Henning

Electric Power Research Institute

$3412 \mathrm{Hillview} \mathrm{Avnue}$

P.0. Box 10412

Palo Alto, CA 94301 
No. of

\section{Copies}

Peter Hoffman

Office of Nuclear Waste

Isolation

$505 \mathrm{King}$ Avenue

Columbus, $\mathrm{OH} 43201$

J. L. Jardine

Argonne National Laboratory

9700 South Cass Avenue

Argonne, IL 60439

J. K. Johnstone

Sand ia Laboratories

Albuquerque, NM 87107

J. A. Kelley

E. I. dePont DeNemours and Company

Savannah River Laboratory

Aiken, SC 29801

C. J. Kershner

Monsanto Research Corporation Mound Laboratory

P.0. Box 32

Miamisburg, $\mathrm{OH} \quad 45342$

J. F. Kircher

Office of Nuclear Waste Isolation

Battelle Memorial Institute

$505 \mathrm{King}$ Avenue

Columbus, $\mathrm{OH} \quad 43201$

D. A. Knecht

Allied Chemical Corporation

550 2nd Street

Idaho Falls, ID 83401

E. H. Kobish

Solid State Division

Oak Ridge National Laboratory

Oak Ridge, TN 37830

D. Lam

Argonne National Laboratory

9700 South Cass Avenue

Argonne, IL 60439
No. of

Copies

Paul W. Levy

Brookhaven National Laboratory

Upton, NY 11973

S. E. Logan

Los Alamos Technical

Associates, Inc.

P.0. Box 410

Los Alamos, NM 87544

Los Alamos Scientific

Laboratory (DOE)

P.0. Box 1663

Los Alamos, NM 87544

J. B. Martin

United States Nuclear Regulatory

Commission

Washington DC 20555

W. C. McClain

RE/SPEC Inc.

P.0. Box 725

Rapid City, SD 57701

M. D. McCormack

E.G. \& G. Idaho, Inc.

P.0. Box 1625

Idaho Falls, ID 83401

She Idon Meyers

DOE Office of Nuclear Waste Management

Washington DC 20545

Don Moak

Office of Nuclear Waste Isolation

$505 \mathrm{King}$ Avenue

Columbus, $\mathrm{OH} 43201$

M. A. Molecke

Sandia Laboratories

Albuquerque, MN 87107 
No. of

Copies

W. E. Mott

DOE Division of Environmental

Control Technology

Washington DC 20545

J. Neff, Program Manager

Department of Energy

Columbus Program Office

505 King Avenue

Columbus, $\mathrm{OH} 43201$

R. M. Neilson, Jr. Department of Applied Science

Brookhaven National Laboratory

Upton, NY 11973

Ed Norr is

Los Alamos Scientific Laboratory

CNC-DO Mailstop 760

Los Alamos, NM 87545

Oak Ridge National Laboratory (DOE)

Central Research Library

Document Reference Library

P.0. Box X

Oak Ridge, TN 37830

G. Oertel

DOE Office of Nuclear Waste

Management

Washington DC 20545

Al Ogle

Los Alamos Scientific Laboratory

CNC-CO Mailstop 760

Los Alamos, NM 87545

A. F. Perge

DOE Office of Nuclear Waste

Management

Washington DC 20545

M. S. Plodinec

E. I. duPont DeNemours and Company

Savannah River Laboratory

Aiken, SC 29801
No. of

Copies

\section{John Pomeroy}

Technical Secretary

National Academy of Sciences

Committee of Radioactive Waste

Management

National Research Council

2101 Constitution Avenue

Washington DC 20418

R. G. Post

College of Engineering

University of Arizona

Tucson, AZ 85721

Professor Guna Salvaduray

Materials Engineering

San Jose State University

San Jose, CA 95192

L. Ramspott

Lawrence Livermore Laboratory

P.0. Box 808

Livermore, CA 94550

D. M. Rohrer

United States Nuclear Regulatory Commission

Washington DC 20555

R. G. Romatowski

DOE Office of Nuclear Waste Management

Washington DC 20545

B. Scheetz

210 Materials Research Laboratory

Pennsylvania State University

University Park, PA 16802

T. Scott

Ames Laboratory

Iowa State University

Ames, IA 50011 
No. of

Copies

W. C. Seymour

E.G. \& G. Idaho, Inc.

P.0. Box 1625

Idaho Falls, ID 83401

M. J. Ste indler

Argonne National Laboratory

9700 South Cass Avenue

Argonne, IL 60439

D. B. Stewart

U.S. Department of Interior

959 National Center

Geological Survey

Reston, Virginia 22092

J. Tewhey

Lawrence Livermore Laboratory

P.0. Box 808

Livermore, CA 94550

John Van Cleve

DOE Oak Ridge Operations Office P.0. Box X

Oak Ridge, TN 37830

E. Vejovoda, Director

Chemical Operations

Rockwe 11 International

Rocky $\mathrm{Flats} \mathrm{Plant}$

P.0. Box 464

Golden, CO 80401

D. L. Vieth

DOE Office of Nuclear Waste Management

Washington DC 20545

R. D. Walton

DOE Office of Nuclear Waste Management

Washington DC 20545

W. Weart

Sandia Laboratories

Albuquerque, NM 87107
No. of

Copies

H. Weed

Lawrence Livermore Laboratory

P.0. Box 808

Livermore, CA 94550

W. White

210 Materials Research Laboratory

Pennsylvania State University University Park, PA 16802

J. B. Whitsett

DOE Idaho Operations Office

P.0. Box 2108

Idaho Falls, ID 83401

A. Williams

Allied-General Nuclear Service P.0. Box 847

Barnwe11, SC 29812

FOREIGN

Dr. P. G. Alfredson

Chief, Chemical Technology Division

Australian Atomic Energy Commission

Research Establishment

Lucas Heights, New South Wales, 2232

Rene Amavis

EURATOM

Health Physics Division

29, Rue Aldringer

Luxembourg

BELGIUM

R. Bonniaud

Center de Marcoule

B.P. 170

30200 Baguols-Sur-Ceze

FRANCE 
No. of

Copies

Bundesministerium fur Forschung und Technologie

Stressemannstrasse 2

5300 Bonn

WEST GERMANY

Center for Atomic Energy

Documentation (ZAED)

Attn: Dr. Mrs. Be11

P.0. Box 3640

7500 Kar lsruhe

WEST GERMANY

D. W. Clelland

United Kingdom Atomic Energy Authority

Risley

ENGLAND

F. Gera

CHEN

CSN Cassaccia L.I.S.

C.P. 24,00 00100

Rome

ITALY

K. B. Harvey

Atomic Energy of Canada, Ltd. W.N.R.E. Pinawa, Manitoba ROE 1 LO

CANADA

Ake Hultgren

Studsvik Energiteknik $A B$

S-611 82 Nykoping

SWEDEN

International Atomic Energy Agency

Kartner Ring 11

P.0. Box 590

A-1011, Vienna

AUSTRIA
No. of

Copies

\author{
K. D. B. Johnson \\ Atomic Energy Research \\ Establishment, \\ Harwe 11, Didcot, \\ Berks \\ ENGLAND
}

Lawrence Johnson

Atomic Energy of Canada, Ltd.

W.N.R.E. Pinawa, Manitoba

ROE 1 LO

CANADA

H. Krause

Kernforschungszentrum Karlsruhe GmbH (KfK)

Postfach 3640

D7500 Karlsruhe

WEST GERMANY

F. Laude

Centre de Marcoule

B.P. 170

30200 Baguols-Sur-Ceze

FRANCE

Hans W. Levi

Hahn-Meitner Institut

1 Berlin 39

G1 ienickerstr. 100

WEST GERMANY

Library

Studsvik Energiteknik $A B$

S-611 01Nykoping

SWEDEN

Werner Lutze

Hahn-Meitner

Institut fur Kernforschung

Berlin, GmbH

Glienicker Strasse

$100, \mathrm{~B}-1000$

Berlin, 39

GERMANY 
No. of

Copies

J. A. C. Marples

Atomic Energy Research

Establishment

Harwe 11, Didcot,

Berks

ENGLAND

E. R. Merz

Institut fur Chemische

Technologie

Kernforschungsanloge Julich

GmbH

$\overline{D 517}$ Julich

Postfach 365

Federal Republic

WEST GERMANY

Ton is Papp

Swed ish Nuclear Supply Co.

SKBF/KBS

Box 5864

S-102 48 Stockholm

SWEDEN

N. S. Aunder Rajan

Bhabha Atomic Research Centre

Goverment of India

Hall No. 5

Trombay

Bombay 8S

INDIA

P. J. Regnaut

Centre d'Etudes Nucleaires de Fontenay-aux Roses

Boite Postale 6

92 - Fontenay-aux Roses

FRANCE

\section{A. Rice}

Department of Ocean Engineering

University of Newcastle upon Tyne

Newcast le up on Tyne, NE I 7 RU ENGLAND
No. of

Copies

Dr. Piero Risoluti,

AGIP NUCLEARE

c/o COMB Casaccia

c.p. 2400

Rome

ITALY

Rolf Sjoblom

Studsvik Energiteknik $A B$

S-611 82 Nykoping

SWEDEN

C. Sombret

Centre de Marcoule

B.P. 170

30200 Baguols-Sur-Ceze

FRANCE

G. G. Strathdee

Atomic Energy of Canada, Ltd.

W.N.R.E. Pinawa, Manitoba

ROE ILO

CANADA

S. Tashiro

Japan Atomic Energy Research Institute

Environmental Safety Research Laboratory

1-1-13, Shibashi

Minatopku, Tokyo

JAPAN

M. Tomlinson

Director of Chemistry and Materials Science Division Atomic Energy of Canada Ltd. Whiteshell Nuclear Research Establishment

Pinawa, Manitoba CANADA

T. T. Vandergraaf

Atomic Energy of Canada, Ltd. W.N.R.E. Pinawa, Manitoba ROE 1LO

CANADA 
No. of

Copies

\section{Lars Werme \\ SKBF/KBS \\ Box 5864 \\ S-10248 Stockholm, SWEDEN}

\section{ONSITE}

5 DOE Richland Operations Office
P. A. Craig
H. E. Ransom
J. J. Schre iber
M. W. Shupe
M. J. Zamorski

11 Rockwell Hanford Operations
J. Babad
M. Bensky
W. E. Coons
R. A. Deju
R. J. Gimera
J. D. Kaser
M. J. Kupfer
W. W. Schultz
M. J. Smith
D. D. Wodrich
File Copy

\section{Exxon Nuclear Company}

S. J. Beard

Joint Center for Graduate Study

J. Cooper

2 United Nuclear Industries, Inc.

T. E. Dabrowski

A. E. Engler

4 Westinghouse Hanford Company
A. G. Blasewitz
D. A. Cantley

No. of

Copies
R. L. Fish
A. C. Leaf

108 Pacific Northwest Laboratory

S. M. Barnes

G. L. Benson

W. J. Bjorklund

H. T. Blair

W. F. Bonner

D. J. Bradley (10)

A. Brandstetter

R. A. Brouns

J. B. Brown, Jr.

J. L. Buelt

R. L. Bunnell

L. A. Chick

T. D. Chikalla

D. B. Cear lock

M. O. Cloninger

G. W. Dawson

W. J. Deutsch

R. D. Dierks

F. H. Dove

J. W. Finnigan

W. J. Gray

M. S. Hanson

F. T. Hara

C. 0. Harvey

0. F. Hill

L. K. Holton

B. Howes

J. H. Jarrett

Y. B. Katayama

W. S. Kelly

R. S. Kemper

D. E. Knowlton

K. M. Krupka

M. R. Kreiter

W. L. Kuhn

D. E. Larson

G. B. Long

R. P. Marshall

J. L. McElroy

G. L. McVay (10)

G. B. Mellinger

J. E. Mende 1 
No. of

Copies

R. D. Nelson

W. R. Nelson

R. E. Nightingale

D. E. Olesen

C. R. Palmer

R. D. Peters

L. R. Pederson

A. M. Platt

D. Rai

J. F. Relyea

F. P. Roberts

W. A. Ross

J. M. Rusin

J. L. Ryan

R. J. Serne

J. W. Shade

D. H. Siemens
No. of

Copies

D. J. Silviera

S. C. Slate

R. G. Strickert

J. L. Swanson

M. T. Thomas

R. T. Treat

R. P. Turcotte

H. H. Van Tuyl

J. W. Wald

W. E. Weber

R. A. Walter

R. Wang

J. H. Westsik, Jr.

L. D. Williams

Technical Information (5)

Publishing Coordination SH/B(2)

Water and Land Resource

Library (10) 


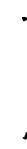

